logical mechanisms, especially those relating to IgE production, ${ }^{21}$ and reduced exposure to anti-idiotype antibodies (thought to be important in the pathogenesis of infantile atopy), ${ }^{212}$ and this may have affected the results. Alternatively, dose related tolerance to cows' milk proteins could develop in immunologically normal preterm or even term infants. Interestingly, Lindfors and Enocksson recently observed that full term infants without a family history of atopy who were fed on formula milk before breast milk had a lower incidence of allergic symptoms up to 18 months. ${ }^{12}$

Our data are relevant to the increasing use of special preterm formulas for low birthweight infants. Although there was no overall increase in allergic reactions when infants were fed on formula rather than human milk, we showed that a familial predisposition to atopy may determine the pattern of allergic response to early diet. The increase in allergic reactions after feeding preterm formula in the subgroup with a family history of atopy, however, must be balanced against mounting evidence of benefits in terms of outcome with special formula milk in neonatal care. ${ }^{23-26}$

1 David TJ. Commentary: prolonged breast feeding and heredity as determinant in infantile atopy. Arch Dis Child 1987;62:273.

2 Autonowicz I, Lebenthal E. Developmental pattern of small intestinal enterokinase and disaccharidase activities in the human fetus. Gastroenterolog 1977;72:1299-303

3 Roberton DM, Paganelli R, Dinwiddie R, Levinsky RJ. Milk antige absorption in the preterm and term neonate. Arch Dis Child 1982;57:369-72.

4 Muller W, Reiger CHL, van der Hardt H. Increased concentrations of milk antibodies in recurrent pulmonary aspiration in infants and young children. Acta Paediatr Scand 1985;74:660-3.

5 Lucas A, McLaughlan P, Coombs RRA. Latent anaphylactic sensitisation of infants of low birth weight to cows' milk proteins. $B r$ Med $\mathcal{F} 1984 ; 289$ : $1254-6$.

6 Lucas A, Gore SM, Cole TJ, et al. Multicentre trial on feeding low birthweigh infants: effects of diet on early growth. Arch Dis Child 1984:59:722-30.

7 Price J. Asthma in children: diagnosis. Br Med f 1984:288:1666-8.
8 Godfrey S. What is asthma? Arch Dis Child 1985;60:997-1000.

Armitage P. Statistical methods in medical research. Oxford: Blackwell. $1971: 429$

10 Van Asperen PP, Kemp AS, Mellis CM. Relationship of diet in the development of atopy in infancy. Clin Allergy 1984;14:525-32.

11 Savilahti E, Taino V-M, Salmenpera L, Siimes MA, Perheentupa J. Prolonged exclusive breast feeding and heredity as determinants in infantile atopy. Arch Dis Child 1987;62:269-73.

12 Lindfors A, Enocksson E. Development of atopic disease after early administration of cow milk formula. Allergy 1988;43:11-6.

13 Bisgaard $H$, Dalgaard $P$, Nyboe J. Risk factors for wheezing during infancy. Acta Paediatr Scand 1987;76:719-26.

14 Kjellman N-IM. Atopic disease in seven-year-old children. Acta Paediat Scand 1977;66:465-71.

15 Croner S, Kjellman N-IM, Eriksson B, Roth A. IgE screening in 1701 newborn infants and the development of atopic disease during infancy. Arch Dis Child 1982:57:364-8.

16 Midwinter RE, Morris AF, Colley JRT. Infant feeding and atopy Arch Dis Child 1987;62:965-7.

17 Taylor B, Wadsworth J, Wadsworth M, Peckman C. Changes in the reported prevalence of childhood eczema since the $1939-45$ war. Lancet 1984;ii: $1255-7$

18 Atherton D, Soothill JV, Sewell M, W'ells RS. A double blind controlled crossover trial of an antigen-avoidance diet in atopic eczema. Luncel $1978 ; \mathrm{i}: 402-4$.

19 Chandra RK. Prospective studies of the effect of breast feeding on incidence of infection and allergy. Acta Paediatr Scand 1979;68:691-9.

20 Michel FB, Bousquet J, Greillier P, Robinet-Levy M, Coulomb Y Comparison of cord blood immunoglobulin $\mathrm{E}$ concentrations and maternal allergy for the prediction of atopic diseases in infancy. 7 Allergy Clin Immunol 1980;65:422-30.

21 Melander L, Carlsson B, Hanson L-A. Secretory IgA and IgM antibodies to coli $\mathrm{O}$ and poliovirus $\mathrm{I}$ antigens occur in amniotic fluid, meconium and saliva from newhorns. A neonatal immune response without antigenic exposurea result of anti-idiotype induction? Clin Exp Immunol 1986;63:555-61.

22 Falth-Magnusson K, Oman H, Kjellman N-IM. Maternal abstention from cow milk and egg in allergy risk pregnancies. Allergy 1987;42:64-73.

23 Brooke $O G$, Wood C, Barley J. Energy balance, nitrogen balance and growth in preterm infants fed expressed breast milk, a premature infant formula and two low-solute adapted formulae. Arch Dis Child 1982;57:898-904.

24 Gross SJ. Growth and biochemical response of preterm infants fed human milk or modified infant formula. $N$ Engl F Med 1983;308:237-41.

25 Lucas A, Morley R, Cole TJ, et al. Early diet in preterm infants and developmental status in infancy. Arch Dis Child 1989;64:1570-8.

26 Lucas A, Brooke OG, Baker BA, Bishop N, Morley R. High alkaline phosphatase activity and growth in preterm neonates. Arch Dis Child 1989:64:902-9.

(Accepted l Fehruary 1990

\title{
Pregnancies in women with and without renal scarring after urinary infections in childhood
}

\author{
Jeanette Martinell, Ulf Jodal, Gunilla Lidin-Janson
}

\section{Abstract}

Objective-To compare the outcome of pregnancy in women with and without renal scarring after childhood urinary infections with that in unmatched controls.

Design-Retrospective study of pregnancies in women prospectively followed up from their first recognised urinary infection.

Setting - Tertiary referral centre in Gothenburg.

Subjects-111 Women attending an outpatient clinic for women with urinary infection during 197583 , of whom 41 (65 pregnancies) were studied (19 women with renal scarring (32), 22 without scarring (33)), and 65 controls (65) randomly selected and matched for parity, age, smoking habits, and date of delivery.

Main outcome measures-Urinary infections and

Departments of Paediatrics and Infectious Diseases, Gothenburg University, East Hospital, S-416 85 Gothenburg, Sweden Jeanette Martinell, MD, senior registrar

Ulf Jodal, MD, senior lecturer Gunilla Lidin-Janson, MD, senior lecturer

Correspondence to: $\mathrm{Dr}$ Martinell, Department of Paediatrics. tions were seen only among women with a history of (three of whom had vesicoureteric reflux) developed pyelonephritis and three cystitis, and one woman without scarring developed pyelonephritis. Mean blood pressure was higher among women with severe renal scarring than controls $(4 / 11 v 3 / 44 ; p<0.05)$ before and during pregnancy. There was no signifi- cant difference in the incidence of pre-eclampsia, operative delivery, prematurity, or birth weight.

Conclusions-Women with a history of previous urinary infections had a high incidence of bacteriuria during pregnancy, and those with renal scarring and persistent reflux were prone to develop acute pyelonephritis. The risk of serious complications in pregnancy, however, was not increased in women with severe renal scarring, possibly owing to their continuous clinical supervision.

\section{Introduction}

The long term risks of pyelonephritic renal scarring - for example, complications during pregnancy - have long been known. ${ }^{2}$ The extent of this risk, however, is inadequately known, depending on factors such as the long follow up required and the difficulty in attaining continuity of data. The aim of this study was to determine the incidence of complications during pregnancy in women followed up continuously since their first recognised urinary tract infection in childhood. Special interest was taken in the rate of infections, prematurity of delivery, pre-eclampsia, and operative delivery in women with and without scarring. urinary infection: four women with renal scarring
Subjects and methods SUBJECTS

There is a long tradition of following up children with urinary tract infections in the Gothenburg area. ${ }^{3+}$ 
When they reach the age of $16-18$ subjects at risk are referred for further long term follow up at the department of infectious diseases at this hospital. Regular check ups are performed once or twice a year and include history, physical examination, recording of blood pressure, culture of urine, and blood sampling. If symptoms suggesting urinary tract infection are found the subjects have immediate access to the emergency room of the department.

All 111 women attending the outpatient clinic for women with urinary tract infection during 1975-83 were included in the study. The records from the departments of paediatrics and infectious diseases were analysed retrospectively. After obtaining the consent of the ethics committee of Gothenburg University the files of the three maternity hospitals in the area were searched for data on pregnancies in the subjects. The files contain all information about deliveries and newborn children as well as the records of the 10-14 control visits at antenatal clinics held during each pregnancy. The control visits include determination of blood pressure, proteinuria, and blood haemoglobin concentration. Screening for bacteriuria is done in the first and third trimesters. All women with bacteriuria are treated, and patients prone to urinary infection are often given antibiotic prophylaxis, which is administered from our clinic or by the antenatal clinic.

Of the 111 women, 42 had given birth ( 66 children, no twin pregnancies) by September 1988. The records for one woman with a single delivery were not available. In the 41 women who could be evaluated the mean follow up time from the first recognised childhood urinary infection was 21.6 years (range 15-37 years). None of the women had hypertension before pregnancy or were receiving antihypertensive treatment. Renal scarring on urography had been found previously in 19 women, five of whom had bilateral scarring, and 22 women had no scarring. By using the kidney with the most severe type of damage to represent each woman with scarring, seven women had mild renal changes, eight severe changes, and three generalised changes. Nephrectomy of a shrunken kidney had been performed in one woman who was included in the group with renal damage, although the other kidney was normal. Four of the women with renal scarring had a glomerular filtration rate below the lower limit of the reference interval for age $\left(85 \mathrm{ml} / \mathrm{min} / 1.73 \mathrm{~m}^{2}\right.$ body surface) measured by clearance of chromium-51 labelled edetic acid one to three years before pregnancy; the rates in these women were $83,78,74$, and $67 \mathrm{ml} / \mathrm{min} / 1.73 \mathrm{~m}^{2}$ respectively.

In 18 of the 19 women with renal scarring vesicoureteric reflux was detected during childhood. In 10 women reflux had resolved on repeat voiding cystourethrography, in six spontaneously and in four after antireflux surgery; in eight reflux persisted at the latest investigation, performed at age 15 or later, in five despite antireflux surgery. In the 22 women without scarring reflux had been found earlier in seven; it resolved spontaneously in six, and one woman had grade 1 reflux at the latest investigation at age 10 .

Controls matched for age, parity, smoking habits, and date of birth were randomly selected from the birth registry for each delivery. Data on the controls were collected as for the index cases (tables I and II).

No systematic evaluation of the socioeconomic state of cases and controls was made; all lived in socially stable areas with good access to medical care.

\section{METHODS}

We obtained midstream samples of urine using the first morning portion or a specimen with an incubation time within the bladder of at least three hours. Bacteriuria on screening during pregnancy was defined as growth of $\geqslant 100000$ colony forming units of one
TABLE I-Clincal details of women with and without renal scarring after childhood urinary tract infection and controls ${ }^{\star}$

\begin{tabular}{|c|c|c|c|}
\hline & With scarring & Without scarring & Controls \\
\hline No of women & 19 & 22 & 65 \\
\hline No of deliveries & 32 & 33 & 65 \\
\hline No para 0 & 19 & 22 & 44 \\
\hline No para 1, 2 & 13 & 11 & 21 \\
\hline \multicolumn{4}{|c|}{ Median age at delivery (years): } \\
\hline Para 0 & $22 \cdot 8$ & $21 \cdot 6$ & $21 \cdot 7$ \\
\hline Para 1,2 & $27 \cdot 6$ & $24 \cdot 3$ & $25 \cdot 2$ \\
\hline \multicolumn{4}{|l|}{ No (\%) smokers: } \\
\hline Para 0 & $8(42)$ & $7(32)$ & $17(39)$ \\
\hline Para 1,2 & $6(46)$ & $3(27)$ & $6(29)$ \\
\hline \multicolumn{4}{|c|}{ No (\%) with bacteriuria: } \\
\hline Para 0 & $9(47)^{\star \star \star}$ & $6(27)^{\star \star}$ & $1(2)$ \\
\hline Para 1,2 & $5(38)$ & $2(18)$ & $2(10)$ \\
\hline \multicolumn{4}{|c|}{ No (\%) having antibiotic prophylaxis: } \\
\hline Para 0 & $9(47)^{\star \star \star}$ & $8(36)^{\star \star \star}$ & $1(2)$ \\
\hline Para 1,2 & $3(23)$ & $3(27)$ & $1(5)$ \\
\hline \multicolumn{4}{|c|}{ Mean initial haemoglobin $(\mathrm{g} / \mathrm{l})$ : } \\
\hline Para 0 & 125 & 124 & 127 \\
\hline Para 1,2 & 131 & 132 & 131 . \\
\hline \multicolumn{4}{|c|}{ Mean last haemoglobin $(\mathrm{g} / \mathrm{l})$ : } \\
\hline Para 0 & 122 & 121 & 125 \\
\hline Para 1,2 & 123 & 122 & 125 \\
\hline
\end{tabular}

* Statistical analysis performed only on para 0 group; ${ }^{\star \star} p<0 \cdot 01$, $\star \star \star p<0 \cdot 001$ compared with controls.

TABLE II-Obstetric data on women with and without renal scarring after childhood urinary tract infection and controls

\begin{tabular}{|c|c|c|c|}
\hline & With scarring & Without scarring & Controls \\
\hline \multicolumn{4}{|c|}{ Investigated pregnancies } \\
\hline \multicolumn{4}{|c|}{ No (\%) with pre-eclampsia: } \\
\hline Para 0 & $2(11)$ & 0 & $1(2)$ \\
\hline Para 1, 2 & 0 & 0 & 0 \\
\hline \multicolumn{4}{|c|}{ No (\%) with operative delivery: } \\
\hline Para 0 & $4(21)$ & $6(27)$ & $5(11)$ \\
\hline Para 1,2 & $1(8)$ & 0 & $3(14)$ \\
\hline \multicolumn{4}{|c|}{ Mcan gestational age (weeks): } \\
\hline Para 0 & $40 \cdot 3$ & $39 \cdot 1$ & $39 \cdot 8$ \\
\hline Para 1,2 & $39 \cdot 5$ & $40 \cdot 1$ & $39 \cdot 3$ \\
\hline \multicolumn{4}{|c|}{ No (\%) delivering before 37 th gestational week: } \\
\hline Para 0 & $1(5)$ & $2(9)$ & $2(5)$ \\
\hline Para 1, 2 & $1(8)$ & 0 & $1(5)$ \\
\hline \multicolumn{4}{|c|}{ Mean birth weight $(g)$ : } \\
\hline Para 0 & 3400 & 3700 & 3400 \\
\hline Para 1,2 & 3500 & 3400 & 3400 \\
\hline \multicolumn{4}{|c|}{ Previous pregnancies } \\
\hline \multirow{2}{*}{$\begin{array}{l}\text { No }(\%) \dagger \text { with } \\
\text { termination of } \\
\text { pregnancy }\end{array}$} & & & \\
\hline & $3(16)$ & $3(14)$ & $21(32)$ \\
\hline \multirow{2}{*}{$\begin{array}{c}\text { No (\%)‡ with } \\
\text { miscarriage }\end{array}$} & & & \\
\hline & $3(16)$ & $2(9)$ & $5(8)$ \\
\hline
\end{tabular}

*Numbers of para 0 and para 1,2 women as in table $I$.

tTotal number of women in each category.

$\dagger$ Total number of women in each cate
$\ddagger$ As percentage of number of women.

bacterial strain per $\mathrm{ml}$ urine in two urine samples without symptoms leading to medical consultation. Pyelonephritis was defined as fever of at least $38 \cdot 0^{\circ} \mathrm{C}$, often with acute costovertebral pain, in women with bacteriuria, with $\mathrm{C}$ reactive protein concentration $>20 \mathrm{mg} / \mathrm{l}$ or a transient decrease in the renal concentrating capacity. A diagnosis of cystitis required acute voiding symptoms such as dysuria and urgency and bacteriuria but absence of signs indicating renal involvement. During pregnancy women with bacteriuria were always given antibiotics. Those with pyelonephritis were treated as inpatients and initially given parenteral antibiotics during a total treatment time of 10-14 days. Women with cystitis were given antibiotics for five to seven days. In all women treated for bacteriuria or receiving antibiotic prophylaxis check up urine cultures were performed every two weeks throughout the pregnancy.

Hypertension was defined as a systolic blood pressure $\geqslant 140 \mathrm{~mm} \mathrm{Hg}$ or a diastolic pressure $\geqslant 90 \mathrm{~mm} \mathrm{Hg}$, confirmed by at least two recordings on different occasions. Hypertension with proteinuria and oedema was required for the diagnosis of pre-eclampsia.

We re-evaluated the women's $x$ ray films; renal scarring on urography was defined as reduction of parenchymal thickness with deformity of the corre- 
sponding calix. ${ }^{6}$ The scarring was classified as $(a)$ mild with one or two scars; $(b)$ severe, affecting more than two calices with some area of normal parenchyma remaining; $(c)$ generalised caliceal deformity with universal but variable parenchymal reduction; or $(d)$ shrunken end stage kidney. Vesicoureteric reflux on voiding cystourethrography was classified on a 5 grade scale. ${ }^{8}$

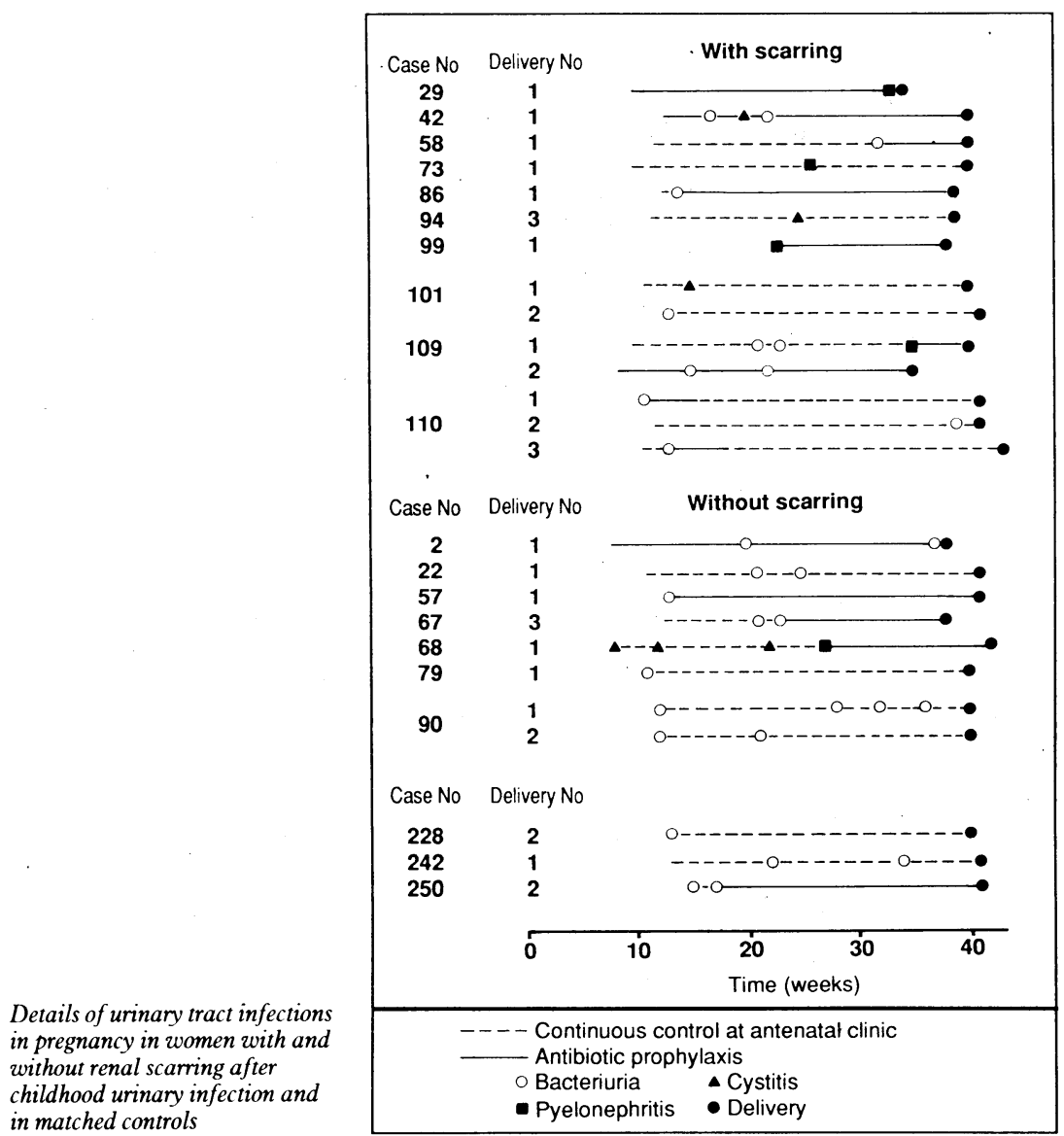

TABLE III - Urinary tract infection during pregnancy in women with renal scarring and vesicoureteric reflux at age 15 or later

\begin{tabular}{|c|c|c|c|c|c|}
\hline Case No & Delivery No & $\begin{array}{l}\text { Age at delivery } \\
\text { (years) }\end{array}$ & $\begin{array}{l}\text { Urinary tract } \\
\text { infection }\end{array}$ & $\begin{array}{c}\text { Grade of } \\
\text { vesicoureteric } \\
\text { reflux (right/left) }\end{array}$ & $\begin{array}{c}\text { Age at examination } \\
\text { (years) }\end{array}$ \\
\hline 16 & $\begin{array}{l}1 \\
2\end{array}$ & $\begin{array}{l}28 \\
31\end{array}$ & $\begin{array}{l}\text { None } \\
\text { None }\end{array}$ & $2 / 2$ & 19 \\
\hline 17 & & 22 & None ${ }^{\star}$ & $0 / 2$ & 24 \\
\hline 29 & $\begin{array}{l}1 \\
2\end{array}$ & $\begin{array}{l}18 \\
19\end{array}$ & $\begin{array}{l}\text { Pyelonephritis } \\
\text { None }\end{array}$ & $2 / 2$ & 20 \\
\hline 34 & $\begin{array}{l}1 \\
2\end{array}$ & $\begin{array}{l}26 \\
29\end{array}$ & $\begin{array}{l}\text { None }^{\star} \\
\text { None } e^{\star}\end{array}$ & $1 / 0$ & 24 \\
\hline 42 & & 20 & Cystitis ${ }^{\star}$ & $0 / 3$ & 25 \\
\hline 48 & & 22 & None ${ }^{\star}$ & $1 / 0$ & 16 \\
\hline 99 & & 21 & Pyelonephritis & $0 / 2$ & 15 \\
\hline 109 & $\begin{array}{l}1 \\
2 \\
3\end{array}$ & $\begin{array}{l}24 \\
26 \\
30\end{array}$ & $\begin{array}{l}\text { Pyelonephritis } \\
\text { Bacteriuria }^{\star} \\
\text { None }^{\star}\end{array}$ & $0 / 1$ & 16 \\
\hline
\end{tabular}

^Antibiotic prophylaxis.

TABLE IV-Blood pressure at last antenatal visit in women (para 0) with and without renal scarring after childhood urinary infection and controls

\begin{tabular}{|c|c|c|c|c|c|}
\hline \multirow{2}{*}{$\begin{array}{l}\text { Extent of scarring after } \\
\text { childhood infection }^{\star}\end{array}$} & \multirow[b]{2}{*}{ No of women } & \multirow{2}{*}{$\begin{array}{c}\text { No with } \\
\text { systolic pressure } \\
\geqslant 140 \mathrm{~mm} \mathrm{Hg}\end{array}$} & \multirow{2}{*}{$\begin{array}{c}\text { No with } \\
\text { diastolic pressure } \\
\geqslant 90 \mathrm{~mm} \mathrm{Hg}\end{array}$} & \multicolumn{2}{|c|}{$\begin{array}{c}\text { Mean (SD) blood pressure } \\
(\mathrm{mm} \mathrm{Hg})\end{array}$} \\
\hline & & & & Systolic & Diastolic \\
\hline \multicolumn{6}{|l|}{$\begin{array}{l}\text { Severe and generalised } \\
\text { scarring (Smellie types }\end{array}$} \\
\hline \multicolumn{6}{|l|}{ Moderate scarring } \\
\hline (Smellie type a) & 8 & 0 & 0 & $119(10 \cdot 3)$ & $74(7 \cdot 3)$ \\
\hline None & 22 & 0 & 2 & $115(7 \cdot 7)$ & $74(8 \cdot 8)$ \\
\hline Controls & 44 & 3 & 1 & $120(9 \cdot 7)$ & $75(7 \cdot 2)$ \\
\hline
\end{tabular}

^According to most severely damaged kidneys.

t $\mathrm{p}<0.05$ Compared with controls.
For statistical comparison of women with a history of urinary infection and controls only first deliveries (para 0 ) were used. The methods applied were Fisher's permutation test and Fisher's exact test. ${ }^{910}$

\section{Results}

Women made their first visit to the antenatal clinic at a median gestation of 12 weeks (range 8-23 weeks).

Bacteriuria with or without symptoms in para 0 women was found significantly more often among women with a history of childhood infection $(15,37 \%)$ than among controls (one, $2 \%)(p<0 \cdot 001)$. The corresponding rate of bacteriuria was $47 \%$ (nine) in women with renal scarring and $27 \%$ (six) in women without scarring $(p=0 \cdot 3)$ (table I). The figure shows details of the infections. Symptomatic infections were seen among women with a history of urinary infection. Four episodes of pyelonephritis and three of cystitis occurred in the 10 women with renal scarring who acquired bacteriuria (14 pregnancies). Of the seven women without scarring who had bacteriuria, only one had pyelonephritis, after three episodes of cystitis.

Antibiotic prophylaxis was given during 12 pregnancies in women with renal scarring (table I); in five it was started after urinary infection during the pregnancy (figure). In three of these women breakthrough infections developed: in one (case 29) acute pyelonephritis caused by antibiotic resistant Escherichia coli and in two (cases 42 and 109) cystitis or bacteriuria on screening caused by antibiotic sensitive $E$ coli. In women without scarring prophylaxis was used during 11 pregnancies, in three of which it was started after episodes of urinary infection (figure). Asymptomatic breakthrough infection was seen in one patient (case 2 ): antibiotic resistant lactobacilli were cultured on four occasions during nine weeks, and resistant $E$ coli was found just before delivery. Among the controls prophylaxis was given to one woman after two episodes of bacteriuria on screening. The drugs used were nitrofurantoin $50 \mathrm{mg}$ (19 women), mecillinam $200 \mathrm{mg}$ (two), and cefadroxil $500 \mathrm{mg}$ (three) in a single bedtime dose.

Among the 19 women with renal scarring, eight still had vesicoureteric reflux at the age of 15 or later (table III). There were 13 pregnancies in these women; antibiotic prophylaxis was given during nine, but three infections were seen, and during the four pregnancies without prophylaxis two attacks of pyelonephritis occurred. Pyelonephritis occurred in three of the eight women with reflux compared with two of the 33 without reflux ( $p=0 \cdot 08)$.

Problems during pregnancy, such as abdominal pain and pruritus, were uncommon and were reported with similar incidence in all groups. Increased blood pressure was not found until late in the pregnancies after the 36th gestational week. During first pregnancies hypertension was significantly more common in the women with severe or generalised renal scarring than in controls (four out of $11 v$ three out of $44, p<0.05$ ). In the same groups the mean blood pressure measured at the last antenatal visit was $125 / 81 \mathrm{~mm} \mathrm{Hg}$ and 120 / $75 \mathrm{~mm} \mathrm{Hg}$ respectively $(\mathrm{p}<0.05)$ (table IV). During second and third pregnancies no women developed hypertension and the mean blood pressures were not significantly different among the groups (table V).

Pre-eclampsia was seen on three occasions, all during first pregnancies, in two of the 19 women with renal scarring and one of the 44 controls, but was not significant (table II). These were the only women given antihypertensive treatment.

The groups did not differ in rate of operative deliveries, length of gestation, or birth weight of the infants (table II). The rate of preterm delivery was low in all groups, but one woman with renal scarring gave 
TABLE $\mathrm{v}-$ Blood pressure at last antenatal visit in women (para 1,2 ) with and without renal scarring after childhood urinary infection and controls

\begin{tabular}{lccccc}
\hline & \multicolumn{2}{c}{$\begin{array}{c}\text { No with } \\
\text { Extent of scarring after } \\
\text { childhood infection }\end{array}$} & No of women & $\begin{array}{c}\text { No with } \\
\text { systolic pressure diastolic pressure } \\
\geqslant 140 \mathrm{~mm} \mathrm{Hg}\end{array}$ & \multicolumn{2}{c}{$\begin{array}{c}\text { Mean (SD) blood pressure } \\
\text { (mm Hg) }\end{array}$} \\
\hline $\begin{array}{l}\text { Severe and generalised } \\
\text { scarring (Smellie types } \\
\text { b and c) }\end{array}$ & 8 & & & & \\
$\begin{array}{c}\text { Moderate scarring } \\
\text { (Smellie type a) }\end{array}$ & 5 & 0 & 0 & $118(8 \cdot 4)$ & $69(7 \cdot 9)$ \\
$\begin{array}{l}\text { None } \\
\text { Controls }\end{array}$ & 10 & 0 & 0 & $116(6 \cdot 5)$ & $74(6 \cdot 5)$ \\
\hline
\end{tabular}

${ }^{\star}$ According to most severely damaged kidneys.

birth in gestational week 34 during an attack of pyelonephritis (case 29 , figure). Mild asphyxia with an Apgar score $<7$ at 1 minute was seen in the infants of three patients without scarring and one control. Malformations observed were one child with Down's syndrome and one with a cleft lip born to women with scarring and one with hypospadias born to a woman in the control group. The general outcome for the infants was good in all groups.

Previous legal abortions had been performed in 21 (32\%) of the controls, which is the expected incidence in the region. The rate among the women with childhood urinary infection (14-16\%, six abortions) was not significantly lower $(\mathrm{p}=0 \cdot 06)$.

\section{Discussion}

This study showed a high rate of bacteriuria on screening, $37 \%$, during 65 pregnancies in women who had had bacteriuria in childhood. In a study of 52 pregnancies in women with symptomless bacteriuria in childhood by Sacks et al the rate was $50 \%$. In both studies the risk of bacteriuria was highest in women with renal scarring, at $47 \%$ and $60 \%$ respectively. ${ }^{1 "}$

The value of screening for bacteriuria during pregnancy has been questioned, and investigations have been performed to elucidate the incidences of bacteriuria and pyelonephritis. There are, however, many difficulties in comparing different studies, depending on such factors as the method of urine sampling - that is, by bladder puncture or from voided urine. There is a risk of underestimating the incidence of bacteriuria in voided specimens when the urinary incubation time within the bladder is short and of overestimating it when the diagnosis is based on a single urine culture. Epidemiological studies from Northwick Park and Aberdeen have illustrated these problems, ${ }^{12}$ and it is difficult to draw definite conclusions. It is important to standardise the method of urine sampling and the follow up programme.

The relevance of growth of lactobacilli, normal constituents of the vaginal flora, in the urine can be determined only by bladder puncture. ${ }^{13}$ However, we considered the finding of lactobacilli in four repeated midstream specimens from the same woman as indicative of true bacteriuria.

In this study the methods of urine sampling were mostly adequate, although in two women the diagnosis of bacteriuria was based on a single urine culture because they were started on planned antibiotic prophylaxis the same day that the culture was performed. In controls the diagnosis of bacteriuria at the antenatal clinic was based on one culture in two of the three cases. Together with the small number of controls this may account for the difference between our rate of $5 \%$ and the cumulative incidence of $1.9 \%$ in a recent epidemiological study performed in the same area in a similar population. ${ }^{14}$ In that prospective study strict methods of diagnosis were used.

Vesicoureteric reflux is strongly related to develop- ment of pyelonephritic renal scarring, which is often called reflux nephropathy; it tends to resolve in growing children but often persists if the reflux was associated with severe ureteric dilatation at detection.' Of our 19 women with renal scarring, eight still had reflux when investigated at the ages of 15 to 25 years; five of them had previously been operated on unsuccessfully.

Pregnancy influences the urinary tract by hormonal and mechanical factors leading to dilatation of the renal pelves and ureters. There is thus an increased ureteric volume and diminished peristaltic activity with an increased bladder volume. ${ }^{16}$ Furthermore, vesicoureteric reflux has been proposed to occur more often during pregnancy compared with after pregnancy. ${ }^{17}$ Reflux and altered urinary flow during pregnancy increase the risk of bacteriuria, leading to renal infection, which is probably further increased by the presence of scarred renal tissue, which is a site of minor resistance due to the decreased perfusion. In pyelonephritis in pregnancy the febrile reaction and the $C$ reactive protein concentration are lower than in non-pregnant women, indicating a depressed inflammatory response during pregnancy. ${ }^{18}$

In our study acute pyelonephritis was seen in four of 32 pregnancies $(13 \%)$ in women with renal scarring but in none of 65 control pregnancies $(p<0.05)$. Antibiotic prophylaxis was used in a third of the women and probably decreased the incidence of bacteriuria as well as acute pyelonephritis. However, breakthrough infections occurred in four pregnancies, two caused by bacteria resistant to the prophylactic drug and two by sensitive bacteria. The finding of sensitive bacteria during prophylaxis is commonly due to non-compliance; other possible explanations in these two patients were vesicoureteric reflux with ureteric dilatation compromising the urine flow (case 42) and nausea with frequent vomiting (case 109). In addition to regular bladder and bowel emptying habits, antibiotic prophylaxis is the most important means of preventing bacteriuria and pyelonephritis in pregnancy. The choice of agent must include consideration of possible toxic effects to the fetus as well as ecological changes leading to selection of resistant bacteria. The acceptance of the drug must be good, which means that drugs increasing nausea should be used with caution. Most drugs used for prophylaxis have a short half life and adequate antibacterial concentrations in the urine for only six to eight hours. A single nightly dose is mostly adequate for prophylaxis in non-pregnant subjects. In pregnancy, however, the increased glomerular filtration rate as well as the altered urine flow may call for a two dose regimen, especially in women with urological anomalies such as vesicoureteric reflux with ureteric dilatation. In women at risk prophylaxis should start as early as possible and continue into the puerperal period.

The mean blood pressure, measured at the last control visit at the antenatal clinic, in women with severe renal scarring was higher than that in those without scarring or in controls. Despite the small numbers this difference was significant $(p<0.05)$ Four of the 11 women with severe scarring had a diastolic pressure $\geqslant 90 \mathrm{~mm} \mathrm{Hg}$ and two of them fulfilled the criteria of pre-eclampsia. The rather low rate of pre-eclampsia in women with renal scarring may be explained by the maintained renal function and the absence of pre-existing hypertension. ${ }^{19}$ One of the two women with pre-eclampsia was the one with the lowest glomerular filtration rate, $67 \mathrm{ml} / \mathrm{min} / 1 \cdot 73 \mathrm{~m}^{2}$; she was also the only woman with proteinuria before pregnancy. In the study by Sacks et al the rate of operative deliveries was increased proportionally to the incidence of pre-eclampsia. ${ }^{11}$

For many years we have had a special interest in 
children with urinary tract infections in Gothenburg. It is crucial to be aware of the high incidence of acute pyelonephritis in infants and small children as early treatment is important to prevent renal scarring. Immediate investigation of the urinary tract is performed in all infants and in older children with renal infections to detect obstructive malformations and vesicoureteric reflux. Patients at risk are continuously followed up through adolescence into adulthood and are repeatedly informed about the future risks and the need for early treatment of renal infections. We believe that this is the reason for the rather low rate of complications and the overall good outcome of pregnancies in our subjects. The low rate of legal abortions in the women with urinary infection in childhood compared with the controls may be another measure of the value of this education and the good access to medical care that these patients have had.

We thank Dr Gunilla Sundell for her help in collecting the data, and Nils Gunnar Pehrsson for the statistical calculations. The study was supported by grants from the Gothenburg Medical Society.

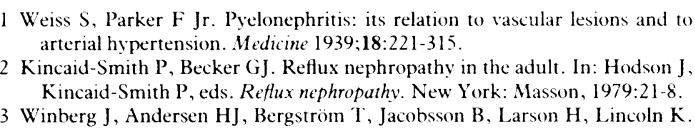

Weiss S, Parker F Jr. Pyelonephritis: its relation to vascular lesions and to arterial hypertension. Medicine 1939;18:221-315.

arteral heperten. Kincaid-Smith P. eds Reflux nephropathy. New York: Masson, 1979:21-8. 3 Winberg J, Andersen HJ, Bergströn T, Jacobsson B, Larson H, Lincoln K.

Eipidemiology of ssmptomatic urinary tract infection in childhood. Actu Paediatr Siand 1974;suppl 252:1-20.

4 Jodal U. The natural history of bacteriuria in childhood. Infectious Disease Climics of North America 1987:1:713-29.

5 (iranerus $G$, Aurell $M$. Reference values for $\mathrm{Cr}$-EDTA clearance as a measure of glomerular filtration rate. Scand 7 Clin Lab Intest 1981;41:61 1-6.

6 Hodson CJ, Wilson S. Natural history of chronic pyelonephritic scarring. BrMed F 1965;ii: 191-4.

7 Smellie J, Edwards D, Hunter N, Normand ICS, Prescod N. Vesico-ureteric reflux and renal scarring. Kidney Int 1975;8:65-72.

8 International Reflux Study in Children. International system of radiographic grading of vesicoureteric reflux. Pediatr Radiol 1985;15:105-9.

9 Odén A, Wedel H. Arguments for Fisher's permutation test. Annals of Statistics 1975;3:518-20

10 Bradley JW. Distribution free statistical tests. London: Prentis Hall, 1968.

11 Sacks SH, Roberts R, Verrier-Jones K, Asscher AW, Ledingham JGG. Effect of symptomless bacteriuria in childhood on subsequent pregnancy. Lancet 1987:ii:991-4.

12 Campbell-Brown M McFadyen IR, Seal DV, Stephenson ML. Is screenin for bacteriuria worth while? $\mathrm{Br}$. Med f 1987;294:1579-82.

13 Persson K, Kvist-Christensen K. Christensen P, Forsgren A, Jörgensen C Persson P-H. Asymptomatic bacteriuria during pregnancy with special reference to group B streptococci. Scand I Infect Dis 1985;17:195-9.

14 Stenqvist $K$, Dahlén-Nilsson I, Lidin-Janson G, et al. Bacteriuria in pregnancy. Frequency and risk of acquisition. Am f Epidemiol 1989;129:372-9.

15 Edwards D, Normand ICS, Prescod N, Smellie J. Disappearance of vesicoureteric reflux during long term prophylaxis of urinary tract infection in children. Br Med J 1977;ii:285-8.

16 Bedoun SN. Morphologic changes in the renal tract in pregnancy. Clin Obstet Gynecol 1985;28:249-56.

17 Mattingly RF, Borkowf HI. Clinical implications of ureteral reflux in pregnancy. Clin Obstet Gynecol 1978;21:863-73.

18 Sandberg T Lidin-Janson G, Svandborg-Eden C. Host response in women with symptomatic urinary tact infection. Scand I Infect Dis 1989;21:67-73.

19 Wuth stme We 1986. A ust NZ 7 Obstet (ivnaecol 1987;27:106-11.

Accepted 2 February 1990
Research Unit, Royal College of Physicians, London NW1 4LE Sheila Howarth, FRCP, coordinator

Cyril Clarke, FRCP, former director

Richard Bayliss, FRCP, former assistant director A G W Whitfield, FRCP, former assistant director

London School of Hygiene and Tropical Medicine, London WC1E 7HT

Joanna Semmence, MSC, postgraduate student M J R Healy, MA, professor of medical statistics

Correspondence to: Sir Cyril Clarke, 43 Caldy Road, West Kirby, Wirral, Merseyside L48 2HF.

Professor Whitfield has since died.

Br.Med f 1990;300:84t-7

\title{
Mortality in elderly patients admitted for respite care
}

\author{
Sheila Howarth, Cyril Clarke, Richard Bayliss, A G W Whitfield, Joanna Semmence, M J R Healy
}

\section{Abstract}

Objective-To determine whether admitting elderly patients to hospital to give temporary relief to their carers is associated with increased mortality.

Design-Prospective multicentre study comparing the mortality of patients admitted on a one off or rotational basis with that experienced while they were awaiting admission.

Setting-A wide range of urban and rural district general, geriatric or long stay, and general practitioner hospitals.

Patients -474 Patients aged 70 or over who had 601 admissions.

Main outcome measure-Death.

Results $-16(3.4 \%)$ Of the 474 patients $(2 \cdot 7 \%$ of all 601 admissions) died while in hospital during an average stay of 15.7 days whereas $23(4.9 \%)$ patients died while awaiting admission (average waiting time was $34 \cdot 2$ days). The 16 deaths in hospital and the 23 deaths during the longer waiting period correspond to death rates of 19.9 and 12.5 per 10000 person days respectively. The difference between these of 7.4 is not statistically significant $(95 \%$ confidence interval

-3.6 to $18 \cdot 3)$. The estimated relative risk of dying in hospital is 1.59 but the $95 \%$ confidence interval is wide $(0.84$ to 3.01$)$.

Conclusion-Although the death rates are slightly higher in those admitted to hospital for relief care than in those awaiting admission, the difference was not significant, and the death rate in both groups was reassuringly small.

\section{Introduction}

A study of 69 elderly patients admitted to the Whittington Hospital in London between July 1980 and February 1983 to give relief or a holiday to their carers found that nine $(13 \%)$ died in hospital-all from bronchopneumonia. ${ }^{.}$Other researchers have also observed a high mortality under similar circumstances. DeLargy reported that of 100 patients admitted every 12 weeks for a six week stay 30 died in hospital over an 18 month period. ${ }^{2}$ Twenty four patients died during their first or second temporary admission. This was not considered unusual in the general wards of a geriatric unit. Four $(9 \%)$ of 46 patients entering a geriatric unit in Glasgow for temporary admission died during their stay and two died immediately after returning home. Ten others who returned home were deemed appreciably worse than on admission and eight, excluding the four who died, never returned home because of deterioration.

In correspondence responding to the disturbing report by Rai et al' mortality of 5\% or less was reported in several hospitals admitting patients for temporary care. ${ }^{+7}$ More recently a retrospective study examining whether psychogeriatric patients aged 65 or over had an increased risk of dying when admitted for relief care found that $19(9 \%)$ of 210 patients, admitted for respite care on 218 occasions died in hospital whereas 29 $(13 \cdot 8 \%)$ died elsewhere, giving a relative risk of dying in hospital of $1 \cdot 14$.

We report a prospective study of the risk of death associated with admitting elderly patients for respite care in hospitals throughout the United Kingdom.

\section{Patients and methods}

All patients admitted to the study were aged 70 or over and incapable of looking after themselves, being cared for at home by one or more carers. The study was carried out prospectively over 12 months from February 1987 . With the help of geriatricians in several centres patients were recruited from various types of hospital (district general, geriatric long stay, general practitioner, or private nursing home) distributed 